\title{
Coalescence of lateral spreading magma ascending through dykes: a mechanism to form a granite canopy (El Hongo pluton, Sierras Pampeanas, Argentina)
}

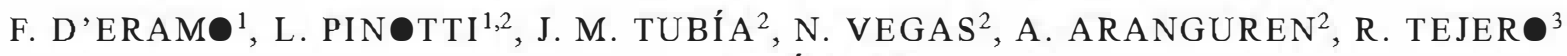 \\ \& D. GÓMEZ ${ }^{3}$ \\ ${ }^{1}$ Departamento de Geología, FCEF Yy V, Universidad Nacional de Río Cuarto, P. . Box 3, E-5800 Río Cuarto, Argentina \\ ${ }^{2}$ Departamento de Geodinámica, F. de Ciencias, Universidad del País Vasco, P. O. 644, E-48080 Bilbao, Spain \\ (e-mail:jm.tubia@ehu.es) \\ ${ }^{3}$ Departamento de Geodinámica, Facultad de Ciencias Geológicas, Universidad Complutense, 28040 Madrid, Spain
}

\begin{abstract}
This study deals with the structure of the El Hongo trondhemite, a ENE-WSW elongate pluton belonging to the Famatinian magmatic arc that developed from Late Cambrian to Silurian times in the Sierras Pampeanas (Argentina). Anisotropy of magnetic susceptibility (AMS) measurements combined with structural and micros ructural data permit the correlation of magmatic and magnetic fabrics within this ferromagnetic pluton. Magnetic foliations strike north-south and dip steeply west but in the marginal facies the foliation becomes parallel to the ENE-WSW pluton contacts. Magnetic lineations mostly rend north-south and plunge SE. Gravity data reveal that the pluton is in the form of a very thin horizontal sheet resting on two north-south-rending root zones detected below the central portion of the pluton. These root zones represent feeder dykes that exploited tension fractures. The emplacement of the El Hongo pluton took place during the action of a buried sinistral shear zone, parallel to the elongation of the pluton, corresponding to a ransfer fault associated with the late extensional exhumation of the Famatinian domain. The emplacement of other Famatinian granites of the Sierras Pampeanas could be related to similar late shear zones.
\end{abstract}

Experimental work on salt tectonics has influenced the thinking about the intrusion of granites so greatly that the ascent of granite magma has until recently been described in terms of diapirism alone (Price \& Cosgrove 1990). For granite plutons emplaced at shallow crustal levels, deformation studies (Hutton 1988, 1992) and theoretical considerations (Vigneresse 1995; Clemens 1998) point to dyking or faulting of the country rocks as alternative, and more efficient, migration mechanisms. This variance in ascent mechanisms does not preclude that analogies between salt diapirs and granite plutons could exist at the emplacement level. In this regard, this study deals with the formation of a granite canopy resulting from the coalescence of two laterally spreading intrusions that were fed through vertical, en echelon fractures. Only by applying a multidisciplinary approach, which combines field structural and anisotropy of magnetic susceptibility data with results from a gravity survey, was it possible to infer that this flatlying canopy of granite was supported by two buried roots. Salt canopies have been recognized in various regions worldwide (Jackson 1995), but equivalent structures are not yet well constrained in granites. A salt canopy is a composite diapiric structure formed by the coalescence of laterally spreading diapir bulbs or salt sheets (Jackson \& Talbot 1993). It differs from a laccolith because a salt canopy is constructed by several intrusions that have pierced the overburden through different feeder stems, whereas a laccolith is a concordant intrusion with a postulated feeder dyke commonly thought to be beneath its thickest point (Corry 1988). It is true that canopy-like structures are implicit in a number of previous studies dealing with the emplacement of granite plutons (Amice \& Bouchez 1989; Tobisch \& Cruden 1995; Aranguren et al. 1996), but typical structures associated with salt canopies, such as the synform generated over the junction of a pair of salt diapirs (Jackson \& Talbot 1993), have not yet been recognized in granite plutons.
The pluton under consideration, referred to as the El Hongo trondhjemite, is a small massif located at the southern corner of the Sierra Chica de Córdoba, the easternmost range of the Sierras Pampeanas, in Argentina (Fig. 1). The Sierras Pampeanas of central Argentina are composed to a great extent of PreMesozoic basement of the Andes that was part of the southern palaeo-margin of Gondwana (Dalla Salda et al. 1992, 1998; Dalziel 1992, 1997). This basement preserves varied geological evidence for the action of successive orogenic cycles that range from the Neoproterozoic Early Cambrian Pampean orogeny (Aceñolaza et al. 1990) to the Devonian Achalian orogeny (Sims et al. 1998), with the intervening Famatinian cycle of Late Cambrian to Silurian age. It is thought that these superimposed orogenic cycles were produced by sequential reactivations of subduction and convergence processes along the Proto-Pacific margin of Gondwana (Pankhurst \& Rapela 1998).

Granites were emplaced during each orogenic cycle (Ortiz Suárez et al. 1992; Llambías et al. 1998; Saavedra et al. 1998). Three main groups of granite rocks are usually recognized in the Sierras Pampeanas, based on their emplacement ages and chemical compositions (Dalla Salda et al. 1992, 1998; Sims et al. 1998). The oldest group, G1, corresponds to pre-Famatinian tonalites to granodiorites of calc-alkaline, metaluminous to peraluminous compositions. These granitoids are frequently transformed into mylonitic rocks as a result of the action of subsequent orogenies. The second group, G2, corresponds to Famatinian monzo- to syeno-granites (Dalla Salda et al. 1998) or to high-Na trondhjemite tonalite units (Rapela et al. 1998). Finally, large, high-K post-tectonic batholiths of Devonian (Sims et al. 1998) or even Early Carboniferous (Dalla Salda et al. 1998) ages are related to the younger Achalian orogeny.

The granite massifs help to constrain the Pre-Mesozoic geodynamic evolution of the Andean belt by placing limits on 


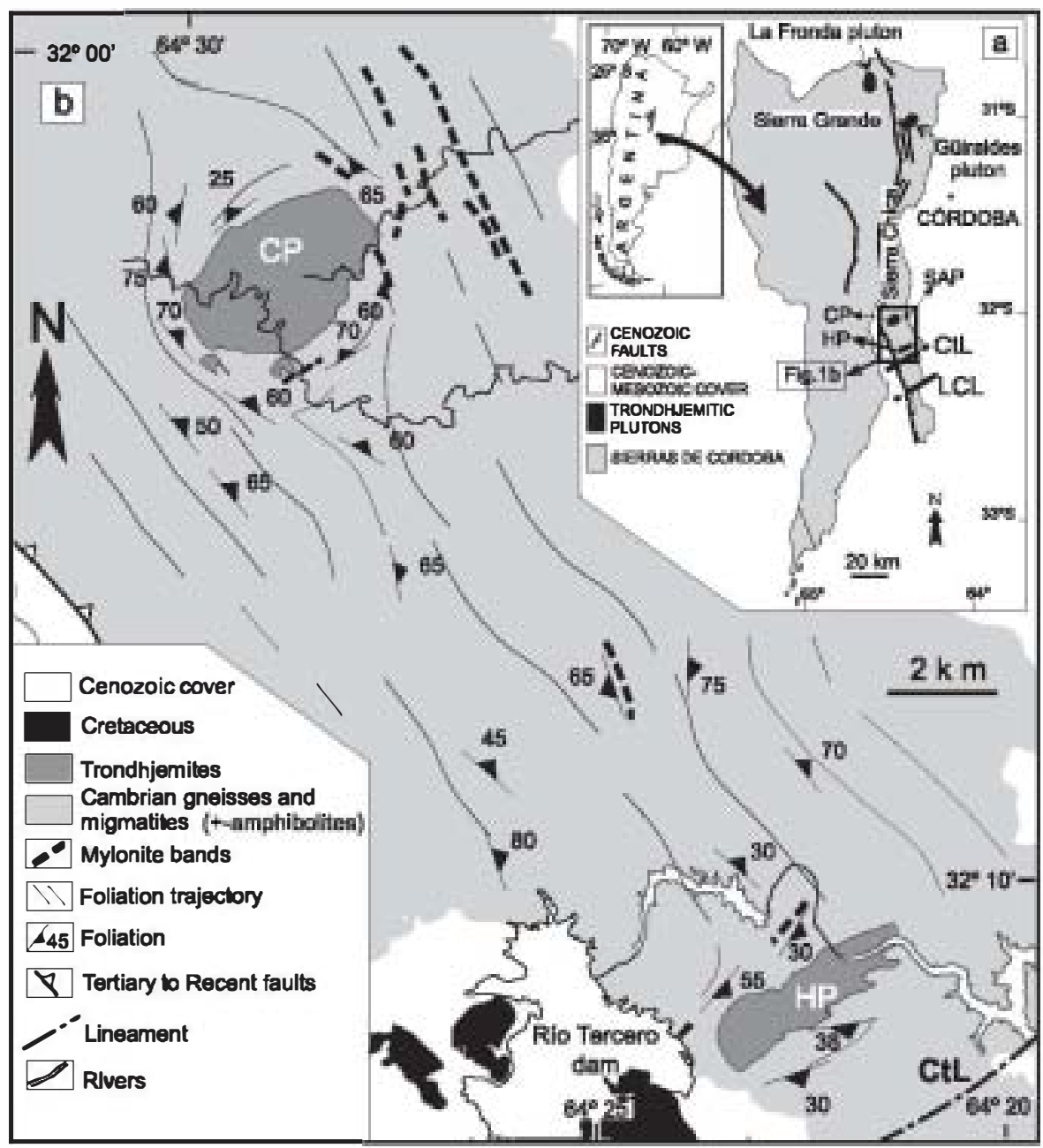

Fig. 1. (a) Location of the studied zone within the Sierras Pampeanas de Córdoba. HP, El Hongo pluton; CP, Calmayo pluton; SAP, San Agustin pluton; CtL, Ctalamuchita lineament, LCL, Los Condores lineament. (b) Simplified geological map of the central sector of the Sierra Chica showing the El Hongo (HP) and Calmayo (CP) plutons and the trajectories of the regional foliation produced during the Famatinian orogeny.

the age of tectonic events and the role of the lithospheric mantle that was actively involved in the magmatism. However, the interpretation of geological information gained from these granite rocks is not straightforward, because of the polyorogenic nature of the basement and the uneven reworking produced by each orogenic cycle in different portions of the Sierras Pampeanas. These factors could account for the discrepancy in views on the Palaeozoic magmatic evolution of the Sierras Pampeanas, as evidenced by the diverging time spans suggested for the Famatinian magmatism: 480500 Ma (Rapela et al. 1998), 42 $460 \mathrm{Ma}$ (Malla Salda et al. 1998) or $4546 \mathrm{Ma}$ (Sims et al. 1998). An additional consequence of the complex tectonic and magmatic evolution of the Sierras Pampeanas is that even the classification of several granite plutons in terms of pre-, syn- and post-kinematic intrusions is difficult (Llambías et al. 1998; Llambías 2003)

Although the El Hongo pluton is post-kinematic with regard to the main regional phases of deformation recognized in the country rocks, the new data presented here point to a tectonically controlled emplacement and provide an opportunity to study the links between emplacement processes and deformational events where there is no other clear structural evidence preserved in the field.

\section{Regional framework}

The basement of the Sierra Chica de Córdoba consists of upper amphibolite-facies to high metamorphic grade gneisses, with minor marbles, amphibolites and ultrabasic rocks, intruded by granitic plutons emplaced at various crustal levels. The protoliths for these rocks have been interpreted as a predominantly clastic sedimentary sequence that was deposited in the accretionary prism of the Pampean subduction system (Malla Salda et al 1992, 1998; Rapela et al. 1998). According to current opinion, the Pampean orogeny reflects the collision between the South American craton and an accreted Pampean terrane (Kraemer et al. 1995; Rapela et al. 1998; Sims et al. 1998). A younger subduction event was established along the same palaeo-margin between 490 and $390 \mathrm{Ma}$ (Pankhurst \& Rapela 1998).

The E1 Hongo pluton belongs to the G2 group of trondhjemite tonalite intrusions associated with the Famatinian subduction event that started at $500 \mathrm{Ma}$ (Rapela et al. 1998). Figure 1a gives the location of the Famatinian G2 granites in the Sierra de Cordoba, with the Güiraldes and La Fronda plutons in its northern sector and the San Agustin, Calmayo and El Hongo plutons in the southern part (Martino et al. 1995; Rapela et al. 1998). Rapela et al. (1998) have interpreted a sensitive highresolution ion microprobe (SHRMP) age of $438 \pm 7 \mathrm{Ma}$ on monazite from the Güiraldes $\mathrm{G} 2$ trondhjemite as dating a resetting event caused by heating associated with post-G2 dextral shearing.

Martino et al. (1995) and Baldo et al. (1996) provided the basis for the tectonic evolution of the Sierras de Córdoba. The structure of the country rocks reflects the overprinting of several deformational events. The oldest structure corresponds to a 
meissic foliation $\left(S_{1}\right)$ that is poorly preserved either in intrafolial D. folds or as an internal foliation in porphyroblasts of garnet or plagioclase. The most penetrative foliation $\left(\mathrm{S}_{2}\right)$ almost obliterates previous structures. The $S_{2}$ schistosity is parallel to the axial plane of kilometre-scale and westward-verging folds that are related to the post-metamorphic exhumation of the region (Martino et al. 1995). Because of the small interlimb angle of such folds, $S_{2}$ becomes parallel to the gneissic layering. $S_{2}$ dips moderately to the east and dominantly strikes NW SE. Within the study area, the trajectories of the foliation show some local deflections towards northward strikes (Fig. 1b). Fold axes are subhorizontal and NW-trending. North- and NW-striking shear zones close in time to $S_{2}$ are also present but neither their regime nor their kinematics is well constrained, and they have been interpreted in various ways: as westward overthrusts (Martino et al. 1995), dextral transpressional shear zones (Stuart Smith et al. 1996) or extensional faults (Whitmeyer \& Simpson 2003). Aerial and satellite images permit the recognition of several lineaments with no clear structural expression in the field, such as the Ctalamochita ENE-striking lineament (Martino et al. 1995) adjacent to the El Hongo pluton.

\section{The granite: field and petrographical features}

The El Hongo pluton is a small massif of nearly rectangular shape ( $4 \mathrm{~km}$ long and $1 \mathrm{~km}$ wide) with an ENE WSW elongation that transects the dominant north south structure of the metamorphic country rocks (Fig. 1). The contacts with the country rocks are sharp, steeply dipping and discordant. In detail, the largest ENE WSW-striking contacts are disrupted and displaced by smaller north south stretches corresponding to faults parallel to the $S_{2}$ schistosity of the country rocks. The roof of the pluton has been preserved by erosion only in the central part of the pluton (Fig. 2), where large blocks of wall rocks overlying the granite are concentrated in a north south-trending corridor corresponding to a depressed synform relative to the nearest outcrops of country rocks.

The El Hongo pluton includes two facies with similar compositions but different textures (Fig. 2). The most abundant rock type is a coarse-grained, hypidiomorphic trondhjemite. Fine-grained porphyritic varieties are restricted to the marginal facies that occur along the northern and southern contacts (Fig. 1b). Contacts between facies are transitional. Dykes with chilled margins intrude these facies. Both the coarse- and fine-grained trondhjemites consist of more than $\mathbf{9 0 \%}$ plagioclase and quartz and less than 10\% mafic minerals. Accessory minerals are biotite, epidote, apatite, zircon and titanite. Minor interstitial Kfeldspar and hornblende are present in a few samples. Chlorite is a secondary mineral commonly found in the eastern half of the massif, as a result of late hydrothermal alterations. Plagioclase has oscillatory and patchy zoned cores and slightly reabsorbed and normally zoned rims (Fig. 3a). Mean core and rim compositions of plagioclase are $\mathrm{An}_{23}$ and $\mathrm{An}_{20}$, respectively. Quartz occurs as large equant aggregates or as small anhedral grains in interstices between plagioclase grains. Biotite is the most abundant mafic mineral. Idiomorphic epidotes armoured in plagioclase and biotite often contain allanite inclusions (Fig. 3b). These textural features are consistent with a magmatic epidote (Sial et al. 1999), which indicates a deep origin and fast ascent of the magma (Zen \& Hammarstrom 1984; Schmidt \& Thompson 1996). Magnetite appears as small $(\bullet .2 \quad 0.5 \mathrm{~mm})$ euhedral to subequant inclusions in biotite (Fig. 3c). Some coarse-grained rocks show graphic intergrowth of quartz and plagioclase. The fine-grained porphyritic trondhjemite is characterized by pheno-

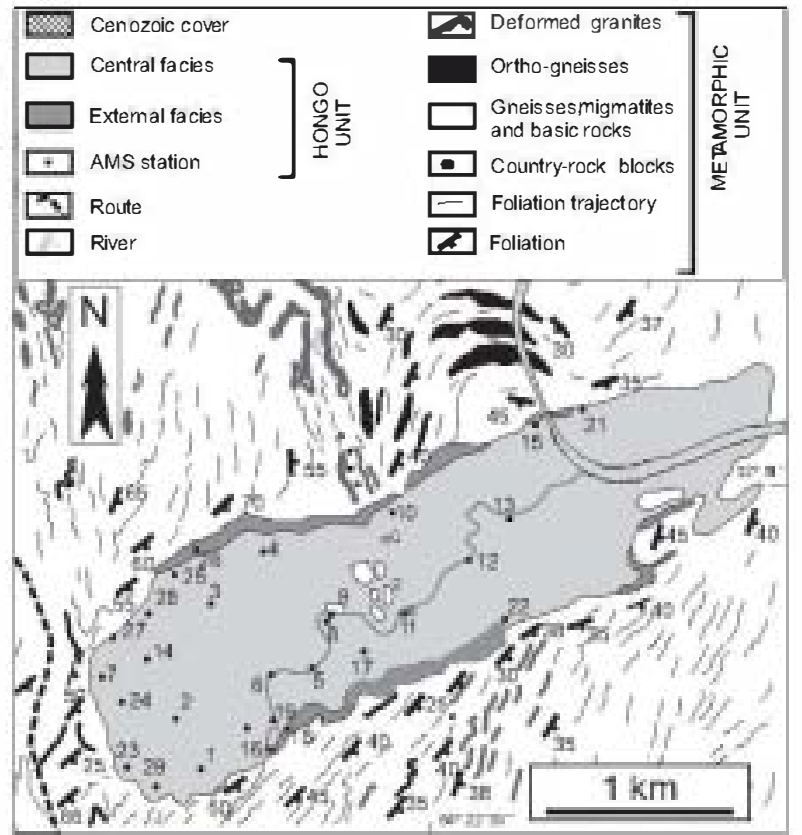

Fig. 2. Geological map of the El Hongo granite. Noteworthy features are the wide distribution of the central, coarse-grained facies and the concentration of the external, fine-grained facies in two narrow bands adjacent to the longer contacts of the pluton. Sructures in the metamorphic counry rocks abut at high angles against the ENE sides of the pluton, suggesting that the granite emplacement post-dates the main structures of the country rocks. Numbered points show the location of stations for the AMS study.

crysts of plagioclase with fine-scale zoning set in a groundmass of phaneritic quartz, plagioclase and biotite. The development of these fine-grained facies suggests that the El Hongo pluton is a shallow intrusion.

Two main types of planar structures of magmatic origin exist within the El Hongo pluton. A foliation can be recognized only in outcrops formed by porphyritic rocks with large plagioclase and biotite crystals that have a well-developed preferred orientation. In contrast, there is a noticeable magmatic layering (Fig. 3e) composed of biotite-rich bands usually less than $1 \mathrm{~cm}$ thick alternating with thicker layers $(23 \mathrm{~cm}$ ) enriched in plagioclase and quartz. The layering is parallel to the foliation and single layers can extend several tens of metres with steep dips and a dominant north south strike (Fig. 3d). Along the northern and southern borders of the pluton, the foliation and magmatic layering have WSW ENE trends parallel to the pluton elongation. No gradual deflection of the layering has been observed from the dominant north south orientation inside the massif to the WSW ENE strike at the pluton borders.

Magmatic structures predominate in the El Hongo pluton but incipient solid-state deformation at high-temperature conditions is imprinted over the magmatic structures within most of the samples from the marginal facies. The magmatic origin of the dominant foliation is evidenced by the coexistence of wellaligned biotite and plagioclase porphyrocrystals with rounded aggregates of quartz, which attests to the lack of solid-state intracrystalline deformation. Samples from the marginal facies contain quartz aggregates with a mosaic microstructure of square 

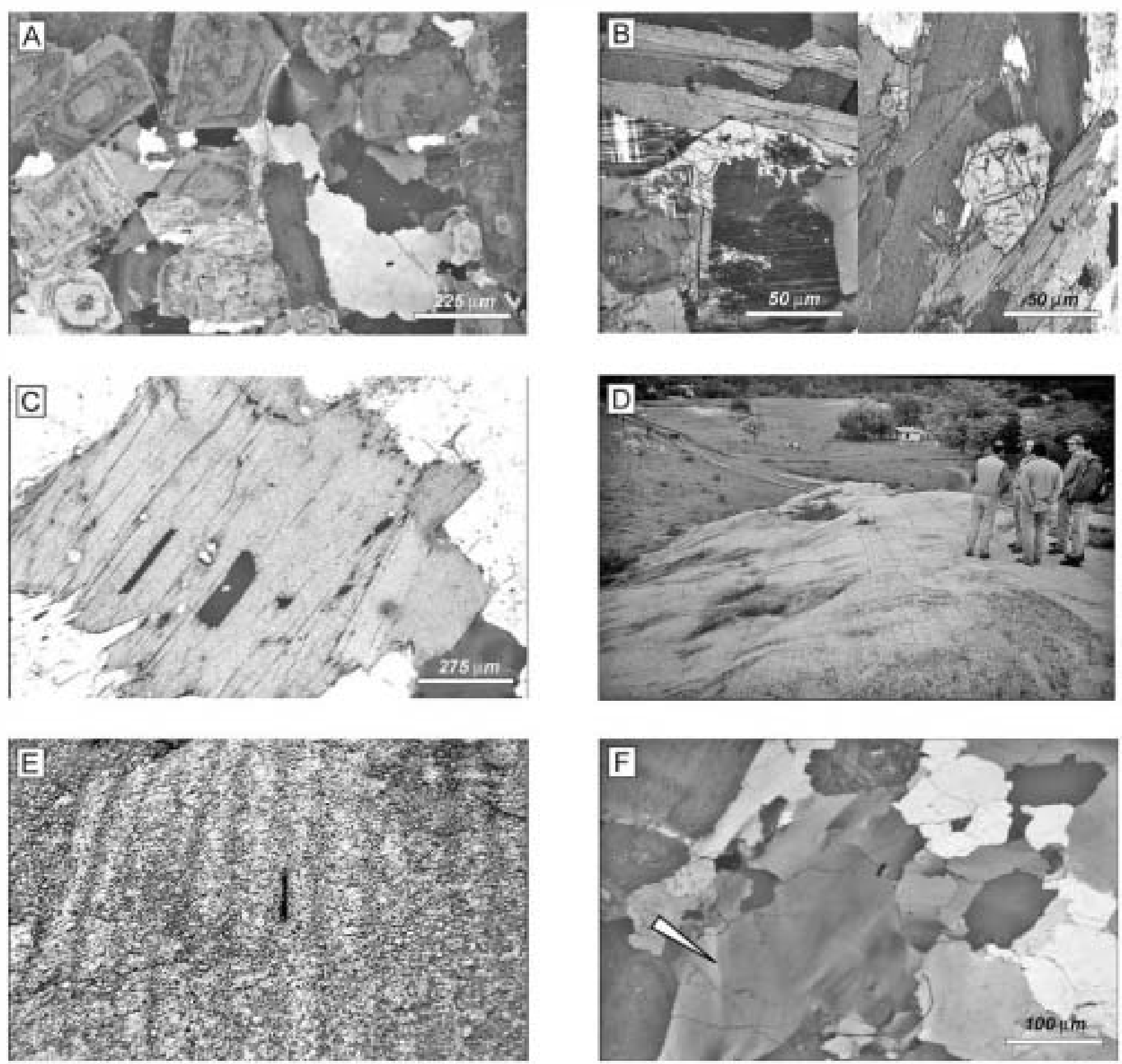

Fig. 3. Field structures of magmatic or gin in the El Honge pluton. (a) Characteristic textre within the magmatic microstuctural domains showing the idiomotphic shape of plazioclase crystals and the lack of intracrystalline deformation in the interstitial grains of quartz. (b) Euhedral mazmatic epidote rimmed by biotite and partially resorbed by the host magma. (c) Euhedral magne tite grains parallel to the biotite cleavage in trondhjemite $\mathrm{H} 3$. (d) Welldefined compositional layers defined by altemation of more mafic and more felsic trondhjemites (site H3). (e) Rhythmic layering, with a typical layer thickness of $1015 \mathrm{~cm}$. The layering is parallel to the granite foliation. (f) Quartz with incipient chessboard pattern (white arrow) affected by hightemperature solid-state deformation, from trondhjemite core $\mathrm{H} 26 \mathrm{a}$.

grains and subgrains (Fi. 3f), indicating high-temperature defermation $\left(>504-55{ }^{\circ} \mathrm{C}\right.$ ) in subselidus cenditions (Mainprice et al. 1986; Blumenfeld \& Beuchez 1988). Such defermation teek place by the end of the crystallization but still at high temperatures, as shewn by the widespread development of mesaic micresucture in quartz grains that display enly a very weak elengation (Fig. 3f). In the NE corner of the pluten, there is brittle shearing leading to penerative micrefracture netwerks and kink-band micresuctures in bietite and chlerite

\section{Anisetrepy of magnetic susceptibility}

The anisorepy of magnetic susceptibility (AMS) in a low magnetic field is now used routinely for the smuctural analysis of granitoids (Bouchez 1997) because it allows a fast and accurate measurement of the directional cempenents of the rock fabric, even if such fabrics are so weakly developed that they cannet be identified by the naked eye. AMS is an excellent toel for unravelling the perofabric of igneous rocks (Hrouda 1982; 
Borradaile 1988; Borradaile \& Henry 1997) and provides a rapid picture of the internal structure of a pluton. In particular, this technique is very useful in the measurement of the linear component of the rock fabric, which is very difficult to recognize in the field (Bouchez 1997).

\section{Sampling and measurements}

This study is based on the analysis of the magnetic susceptibility of oriented samples from 29 sites chosen to obtain a coverage as regular as possible of the entire surface of the El Hongo pluton (Fig. 2). Two or three oriented cores per site were extracted with a portable drilling machine, and two cylindrical samples $(25 \mathrm{~mm}$ in diameter and $22 \mathrm{~mm}$ high) were obtained from each core, affording 120 measured specimens. Thin sections were made for each station to correlate the ASM parameters with mineralogy and microsmuctures. The specimens were analysed using a Kappabridge KLY-2 susceptometer (Geofysica, Bmo), working in a low alternating field (a.f.; $4 \times 10^{4} \mathrm{~T}$; $920 \mathrm{~Hz}$ ) with resolution better than $5 \times 10^{8}$ SI units. Each specimen was measured in 15 directions, allowing the calculation of magnitudes and orientations of the three principal axes of the AMS ellipsoid $\left(K_{1} \geqslant K_{2} \geqslant K_{3}\right)$.

The magnetic susceptibility, $K$, is defined by the ratio between the induced magnetization of the material and the inducing magnetic field For each station, the bulk susceptibility, $K$, represents the average of the arithmetic means of the $K_{1}, K_{2}$ and $K_{3}$ magnitudes of the specimens $\left(\left(K_{1}+K_{2}+K_{3}\right) / 3\right)$. The diamagnetic constant was subracted from all the samples. The magnetic lineation (parallel to $K_{1}$ ) and foliation (normal to $K_{3}$ ) for each station were computed from the averages of the $K_{1}$ and $K_{3}$ orientations of individual specimens. The degree of anisotropy and shape of the AMS ellipsoid were studied by using the $P^{\prime}$ and $T$ parameters of Jelinek (1981). The anisorropy degree, $\boldsymbol{P}^{\prime}$, varies from $P^{\prime}=1$ (isotropic, spherical AMS ellipsoid) to infinity. The shape parameter, 2 , varies between $T=-1$ (prolate ellipsoids) and $T=+1$ (oblate ellipsoids). These parameters are defined by the following expressions:

$$
\left.P^{\prime}-\exp \left(2\left(\mu_{1}-\mu_{n}\right)^{2}+\left(\mu_{2}-\mu_{n}\right)^{2}+\left(\mu_{1}-\mu_{n}\right)^{2}\right]\right)^{1 / 2}
$$

$$
T=\left(2 \mu_{2}-\mu_{1}-\mu_{1}\right) /\left(\mu_{1}-\mu_{3}\right)
$$

where $\mu_{1}=\ln K_{\text {maximum }}, \mu_{2}=\ln K_{\text {intermediate }}, \mu_{3}=\ln K_{\text {mirumum }}$, and $\mu_{\mathrm{m}}=$ $\ln K_{\text {medium }}$

\section{Mineralogy and magnetic susceptibility}

Depending on their mineralogy, granites may show paramagnetic or ferromagnetic behaviour. In paramagnetic granites, the magnetic susceptibility is due essentially to the contribution of Febearing silicates such as biotite or amphibole (Bouchez 1997). In ferromagnetic granites, the paramagnetic contribution of $\mathrm{Fe} \mathrm{Mg}$ silicates may become negligible with respect to the ferromagnetic contribution because of the high intrinsic magnetic susceptibility of the ferromagnetic minerals (usually magnetite). A precise knowledge of the magnetic mineralogy of a rock is required for the interpretation of the results obtained with the AMS technique, notably as regards quantification. This is particularly important when susceptibility is due to various mineral phases and when their magnetic subfabrics are not coaxial (Rochette et al. 1992).

The mean magnetic susceptibility, $K$, varies from $5.75 \times$ $10^{-6}$ SI to more than $8700 \times 10^{-6}$ SI (Table 1). Samples from only seven sites provide $K$ values lower than $300 \times 10^{-6} \mathrm{SI}$ typical of paramagnetic granitoids, which suggests that their magnetic fabric mainly reflects the orientation of biotite, the only

\begin{tabular}{|c|c|c|c|c|c|}
\hline Site & $K$ & $P^{\prime}$ & $T$ & $K_{1}$ & $K_{3}$ \\
\hline H1 & 1966.5 & 1.26 & 0.47 & $356 / 10$ & $265 / 2$ \\
\hline $\mathrm{H} 2$ & 3579.13 & 1.16 & 0.34 & $342 / 64$ & $254 / 3$ \\
\hline $\mathrm{H} 3$ & 249.9 & 1.06 & 0.08 & $182 / 37$ & $299 / 18$ \\
\hline $\mathrm{H} 4$ & 57.5 & 1.02 & 0.01 & $115 / 40$ & $14 / 001$ \\
\hline H5 & 833.97 & 1.15 & 0.26 & $178 / 47$ & $271 / 2$ \\
\hline H6 & 1258.23 & 1.19 & $\bullet .53$ & $203 / 60$ & $99 / 9$ \\
\hline $\mathrm{H} 7$ & 4786 & 1.14 & 0.68 & $175 / 23$ & $80 / 9$ \\
\hline $\mathrm{H} 8$ & 1172.6 & 1.23 & 0.62 & $190 / 42$ & $93 / 5$ \\
\hline $\mathrm{H} 9$ & 4067.03 & 1.27 & 0.28 & $356 / 10$ & $265 / 2$ \\
\hline $\mathrm{H} 1 \bullet$ & 151.93 & 1.11 & 0.56 & $215 / 49$ & $102 / 15$ \\
\hline H1l & 487.63 & 1.26 & 0.54 & $189 / 9$ & $99 / 6$ \\
\hline H12 & 3914.03 & 1.19 & 0.45 & $182 / 17$ & $80 / 33$ \\
\hline H13 & 622.47 & 1.08 & 0.22 & $189 / 20$ & $90 / 30$ \\
\hline H14 & 160.77 & 1.19 & 0.41 & $37 / 73$ & $289 / 4$ \\
\hline H15 & 454.63 & 1.11 & 0.67 & $15 / 46$ & $137 / 28$ \\
\hline H16 & 8757.83 & 1.19 & 0.42 & $188 / 60$ & $79 / 12$ \\
\hline H18 & 4479.5 & 1.05 & 0.08 & $177 / 8$ & $106 / 12$ \\
\hline H19 & 732.57 & 1.3 & $\bullet .71$ & $353 / 56$ & $87 / 5$ \\
\hline $\mathrm{H} 2$ & 2026.77 & 1.24 & 0.59 & $208 / 48$ & $101 / 27$ \\
\hline $\mathrm{H} 21$ & 20.06 & 1.05 & $-\bullet .11$ & $278 / 39$ & $162 / 34$ \\
\hline $\mathrm{H} 22$ & 819.97 & 1.17 & -0.06 & $187 / 39$ & $89 / 8$ \\
\hline $\mathrm{H} 23$ & 719.57 & 1.1 & 0.39 & $196 / 56$ & $90 / 10$ \\
\hline $\mathrm{H} 24$ & 664.53 & 1.1 & $\bullet .51$ & $344 / 11$ & $75 / 4$ \\
\hline $\mathrm{H} 25$ & 605.63 & 1.33 & 0.82 & $113 / 7$ & $232 / 74$ \\
\hline $\mathrm{H} 26$ & 139.33 & 1.11 & 0.06 & $205 / 42$ & $001 / 46$ \\
\hline $\mathrm{H} 27$ & 808.43 & 1.09 & 0.59 & $180 / 17$ & $271 / 13$ \\
\hline $\mathrm{H} 28$ & 659.17 & 1.3 & 0.49 & $187 / 25$ & $81 / 28$ \\
\hline $\mathrm{H} 29$ & 6570.73 & 1.33 & 0.49 & $183 / 37$ & $83 / 12$ \\
\hline
\end{tabular}

Table 1. AMS dat for 29 sumpling stations of the El Hong pluton

$K$, magnitude of the magnetic susceptibility (in $\mu \mathrm{SI}$ ); $\boldsymbol{P}^{\prime}$, anisotropy degree; 1 ; shape parameter; $K_{1}$, azimuth and plunge (in degrees) of the magnetic lineation; $K_{3}$, azimuth and plunge (in degrees) of the pole of the magnetic foliation. 
Fe-bearing silicate in the El Hongo pluton. Values of $K$ greater than $300 \times 10^{-6}$ SI ( $83 \%$ of sites) suggest that ferromagnetic minerals, probably magnetite, make significant contributions to the magnetic susceptibility (Rochette 1987; Bouchez 1997).

The nature of the magnetic phases was determined using a CS-2 furnace apparatus coupled to the Kappabridge KLY-2 susceptometer. The magnetic susceptibility of a small amount of crushe sample $\left(.25 \mathrm{~cm}^{3}\right)$ was measured at rising temperature, from 25 to $700^{\circ} \mathrm{C}$, in an argon atmosphere to prevent oxidation during heating. Figure 4a shows the variation of $K$ with temperature. The analysed samples were selected to cover the whole range found in the El Hongo pluton; they include the specimen with the highest susceptibility ( $\left.\mathrm{H} 29, K=657 \times 10^{-6} \mathrm{SI}\right)$ and samples with intermediate $\left(\mathrm{H} 9, K=406 \times 10^{-6} \mathrm{SI}\right)$ and low $K$ values $\left(\mathrm{H} 3, K=249 \times 10^{-6} \mathrm{SI}\right)$. The heating run of sample $\mathrm{H} 29$ reflects the presence of magnetite, as shown by the gentle increase in susceptibility with rise in temperature owing to the Hopkinson effect and the sudden drop of susceptibility at $c$. $580^{\circ} \mathrm{C}$, the Curie temperature for this mineral (Fig. 4a). Sample $\mathrm{H}$ is characterized by fairly constant $K$ until the Curie point $\left(575^{\circ} \mathrm{C}\right)$, after which it drops. The temperature at which the drop occurs suggests the presence of magnetite. The curve for sample $\mathrm{H} 3$, which has the smallest magnetic susceptibility, remains constant up to $460^{\circ} \mathrm{C}$ then rises, followed by a drop at $580^{\circ} \mathrm{C}$, suggesting the presence of trace amounts of a ferromagnetic phase, which is transformed to magnetite during the heating run

\section{Anisotropy of remanent magnetization}

The anisotropy of remanent magnetization has been studied in magnetite-bearing samples with high and intermediate $K$ values, to determine the preferred orientation of magnetite grains. Remanent coercivity spectra were obtained deriving the curve values from the magnetization of the sample by applying a small steady field ( $500 \mu \mathrm{T}$ d.c. field), superimposed on an a.f. of $100 \mathrm{mT}$, followed by gradual demagnetization by an a.f. field Remanence was measured using an LDA3-AMU1 demagnetizer anhysteretic magnetizer and a JR5A magnetometer manufactured by Agico.

The resulting spectra (Fig. $4 \mathrm{~b}$ and c) show a unimodal distribution having low-coercivity carriers. Because coercivity is inversely linked to grain size (Jackson et al. 1988; Jackson 1991; Trindade et al. 2001) these samples appear to be dominated by large magnetite grains, supposed to be in a multidomain range. The anisotropy of remanent magnetization (ARM) was measured in samples $\mathrm{H}$ and $\mathrm{H}_{2}$, using the anisotropy of partial anhysteretic remanence (pAAR) (Jackson et al. 1988). This procedure consists of cycles of anhysteretic remanence acquisition, measurements and demagnetization at different positions for each sample. A six position measurement scheme was used, which corresponds to three mutually orthogonal positions and their opposite directions. The anisotropy of partial anhysteretic remanence was determined in the $220 \mathrm{mT}$ ( $\mathrm{pAAR} \mathbf{R}_{2}$ 20) window, which includes $67 \%$ of the bulk magnetization of the samples (shaded areas in the remanent coercivity spectra shown in Fig. 4b and c). This range was chosen to avoid the effect of parasitic viscous remanences from the first steps, $2 \mathrm{mT}$, and instability at $>20 \mathrm{mT}$.

The $\mathrm{pAAR}_{2} 20$ fabric is assumed to reflect the preferred orientation of large magnetite grains and is coaxial to the AMS ellipsoid (Fig. 4b and c). This indicates that pAAR $\mathbf{R}_{2} 0$ and AMS fabrics could be interpreted in the same way at sites where ferromagnetic minerals carry most of the bulk magnetic susceptibility. It is now well established that in ferromagnetic granites
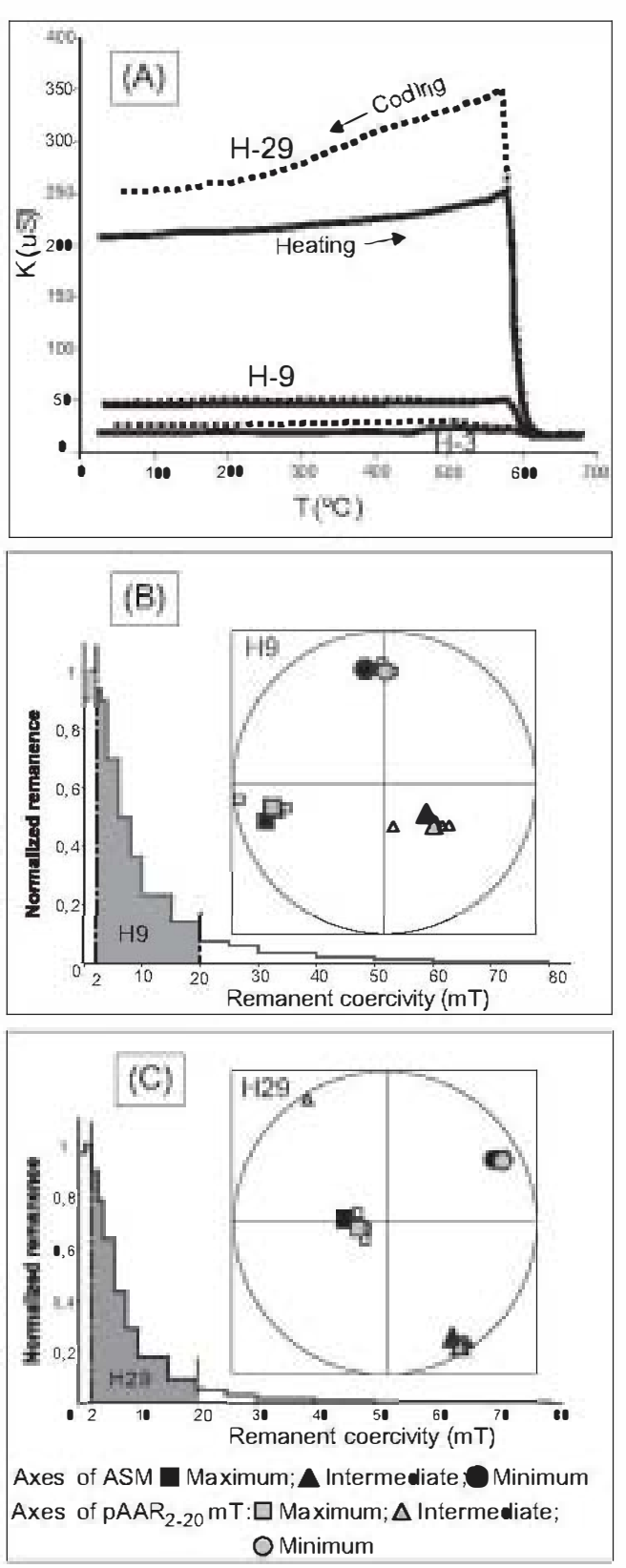

Fig. 4. (a) Susceptibility v. temperature curves for three specimen of the El Hongo rondhemite. The susceptibility falls abruptly between 570 and $585^{\circ} \mathrm{C}$, indicating the presence of magnetite. Sample $\mathrm{H} 29$ shows a slight increase in magnetic susceptibility related to the Hopkinson effect. (b, c) Remanent coercitivity spectra and lower-hemisphere stereoplots of anisotropy of partial anhysteretic remanence from 2 to $20 \mathrm{mT}$ (pAAR 20) for sites $\mathrm{H} 9$ (b) and $\mathrm{H}_{2} 9$ (c). In the coercitivity spectra, intensities of remanence are normalize to the highest value of partial remanence acquisition; the grey portion represents the total magnetization corresponding to the $\mathrm{pAAR}_{2}-2 \mathrm{mT}$ window. In the stereoplots, black symbols give the maximum, intermediate and minimum tensors of AMS; grey symbols give the maximum, intermediate and minimum tensors of pAA $\mathbf{R}_{2}-2$. The open symbols represent the six measure positions required to obtain the $\mathrm{pAAR}_{2}-2$ tensors.

the AMS mainly reflects the shape fabric of grains of magnetite (Grégoire et al. 1998). Because in the E1 Hongo pluton magnetite grains are elongate parallel to the biotite cleavage (Fig. 3e), the measured magnetic fabrics afford accurate images of the rock 
fabric and therefore can be used to infer the internal structure of the pluton. This conclusion is supported by the good correlation between the magnetic foliation and the field foliation, and is also consistent with the lack of clusters of magnetite grains, which could produce magnetic interactions between neighbouring gains that would lead to anomalous magnetic fabrics (Bouchez 1997).

\section{Magnetic fabric patterns}

The ASM ellipsoid-shape parameter $(T)$ varies between $-\mathbf{0 . 0 6}$ and 0.82 with a mean value of 0.36 (Table 1). The majority of the sites fall within the flattening field $(<T<1)$ indicative of dominant oblate magnetic fabrics.

At most of the sampled sites, magnetic fabrics show a rather homogeneous orientation characterized by pronounced obliquity between the magnetic foliation and the pluton elongation (Fig.

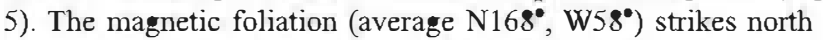
south and dips steeply to the west throughout the granite massif, except for a narrow zone close to the northern contact, where the foliation becomes parallel to the contact (Fig. 5). Although the advanced alteration along the southern border zone precludes the extraction of samples for AMS analyses, field observations reveal foliations parallel to the contact in that sector (Fig. 5). In those outcrops where layering or magmatic foliation have been observed, both planar structures have the same orientation. Figure $5 \mathrm{~b}$ shows the parallelism between the two fabrics at two distinct sites. Microstructural observations on $x z$ thin sections lend support to the concordance between the magmatic and magnetic

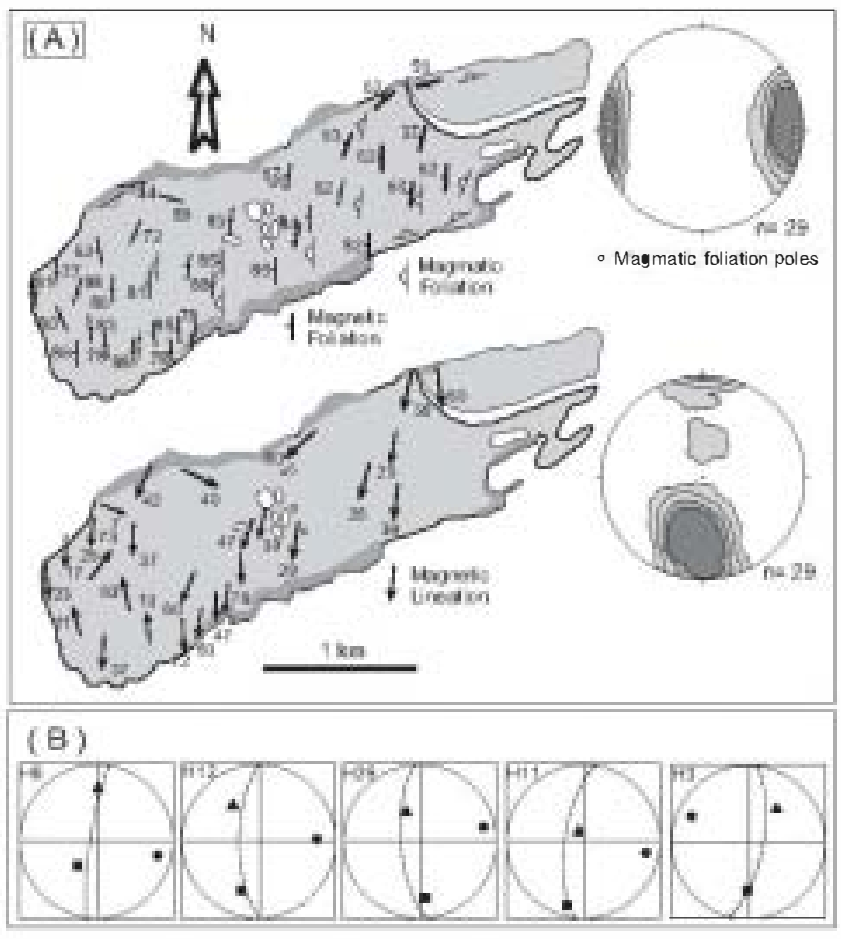

Fig. 5. (a) Magnetic structures, foliation and lineation, in the El Hongo pluton. Orientation diagrams (equal area, lower hemisphere, contours: - $8,1.6,2.4,3.2 \%$ ). (b) Comparison between AMS and field data. AMS average data are represented by $K_{1}(\boldsymbol{\bullet}), K_{2}(\boldsymbol{\Delta})$ and $K_{3}(\bullet \geqslant)$. Dashed line indicates foliation as measured in the field. Location of site is shown in Figure 2. foliations, as magnetite grains are usually found as elongate inclusions parallel to the $(01)$ cleavage of the host biotite crystals (Fig. 3e). It is worth noting that all along the southern border zone the foliation of the coarse-grained samples abuts at high angle against the contact with the country rocks (Fig. 5a), which agrees with the field observation of a sharp structural change from the central coarse-grained facies to the marginal fine-grained facies. The magnetic lineation trends north south and plunges steeply to the south (average lineation: $60^{\circ} / 188^{\circ}$ ), except in the narrow corridor that forms the northern border zone. Plunges greater than $50^{\circ}$ are concentrated in the eastern part of the southwestern quadrangle (Fig. 5a), suggesting the existence of a possible root zone below that area.

\section{Gravity data and 3D geometry}

A gravity survey was carried out over the granite and surrounding areas of country rocks to investigate the shape of the pluton at depth. Within the pluton, the average spacing between gravity stations was $c .300 \mathrm{~m}$. Outside the massif data were collected along mountain tracks at an average spacing of $1 \mathrm{~km}$. Gravity measurements were made with a Lacoste \& Romber gravimeter with a precision of $\pm \mathbf{0 1} \mathbf{m G a l}$. Elevation data were determined using a barometric altimeter with a precision of $\pm .5 \mathrm{~m}$, equivalent to $\pm .1 \mathrm{mGal}$. Gravity and elevation measurements were acquired in cycles of less than $2 \mathrm{~h}$ to minimize drift. Measured stations were located in places with smooth topography so that the effects of topography around the stations can be neglected. Terrain corrections were calculated from $15 \mathrm{~m}$ to a distance of $22 \mathrm{~km}$ using a density of $2.67 \mathrm{~g} \mathrm{~cm}^{-3}$.

The normal gravity at sea level was determined using the World Geodetic System (WGS'84) formula. The density reduction used was $2.67 \mathrm{gm}^{-3}$. Bouguer anomaly data are relative because of the lack of a calibration base station of known absolute gravity value. Gravity data were interpolated by kriging to a regular grid of $250 \mathrm{~m} \times 25 \mathrm{~m}$ to produce a Bouguer anomaly map and showed a distinct east west regional trend, which is transverse to the gravity low associated with the pluton and also to the pluton boundaries. This regional trend, assumed to be due to deep sources, was removed by using a seconddegree polynomial surface. Figure 6 a shows the residual anomaly map obtained. The Hongo pluton produces an overall residual anomaly with an amplitude of about $7 \mathrm{mGal}$ and a NNE SSW trend. Two negative residual anomalies and a positive one characterized by shorter wavelength and trending north south to NNE SSW overprint the large one

The dimensions, density contrast and depth of an anomalous gravity source, such as a granite body, affect the appearance of the gravity anomaly. To investigate pluton dimensions and geometry we modelled the residual anomaly. Four density models crossing the minimum anomaly values were constructed. Two models are transverse to the pluton main axis and the other two are parallel to this axis (Fig. 6b). Each model consists of two density bodies representing the trondhjemite and the host rock. The end effects owing to the limited lateral extent of the pluton were corrected considering it as a $2 \mathbf{D}$ structure. From density measurements of rock samples, we find that trondhjemite and host rock main densities are $2.64 \mathrm{~g} \mathrm{~cm}^{-3}$ and 2.78 $\pm 0.04 \mathrm{~g} \mathrm{~cm}^{-3}$, respectively. The geometry and density were adjusted until the discrepancies between the model anomaly and the residual anomaly were smaller than an error of $1 \%$. The best fit was achieved by using a density of $2.64 \mathrm{~g} \mathrm{~cm}^{-3}$ for the trondhjemite and $2.82 \mathrm{~g} \mathrm{~cm}^{-3}$ for the host rock. Observed minimum residual anomalies were matched with deeper extents of 

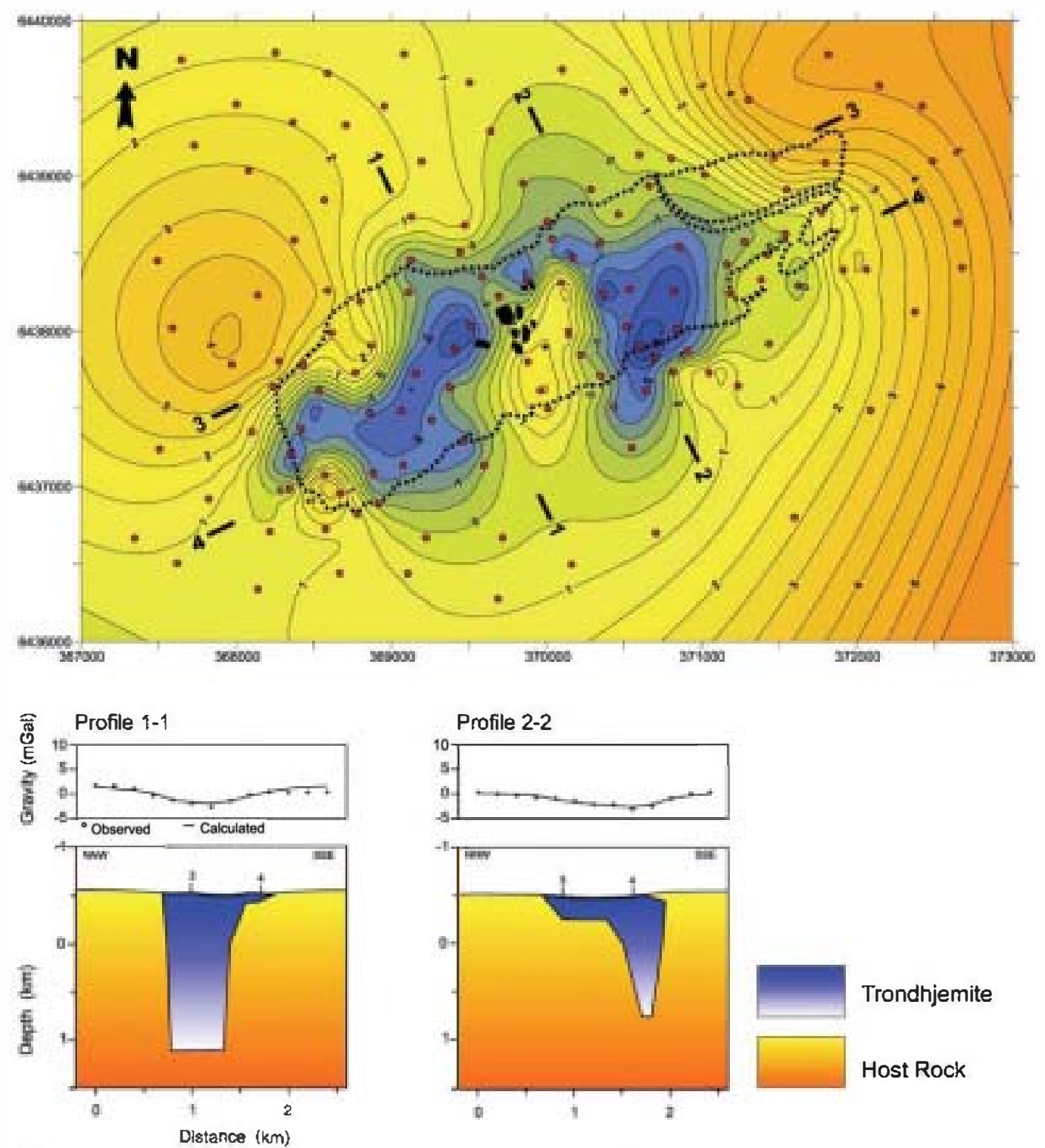

Trondhjemite

Host Rock

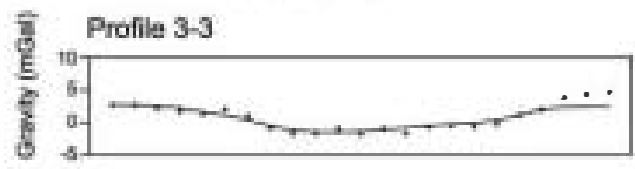

\section{Profile 4.4}
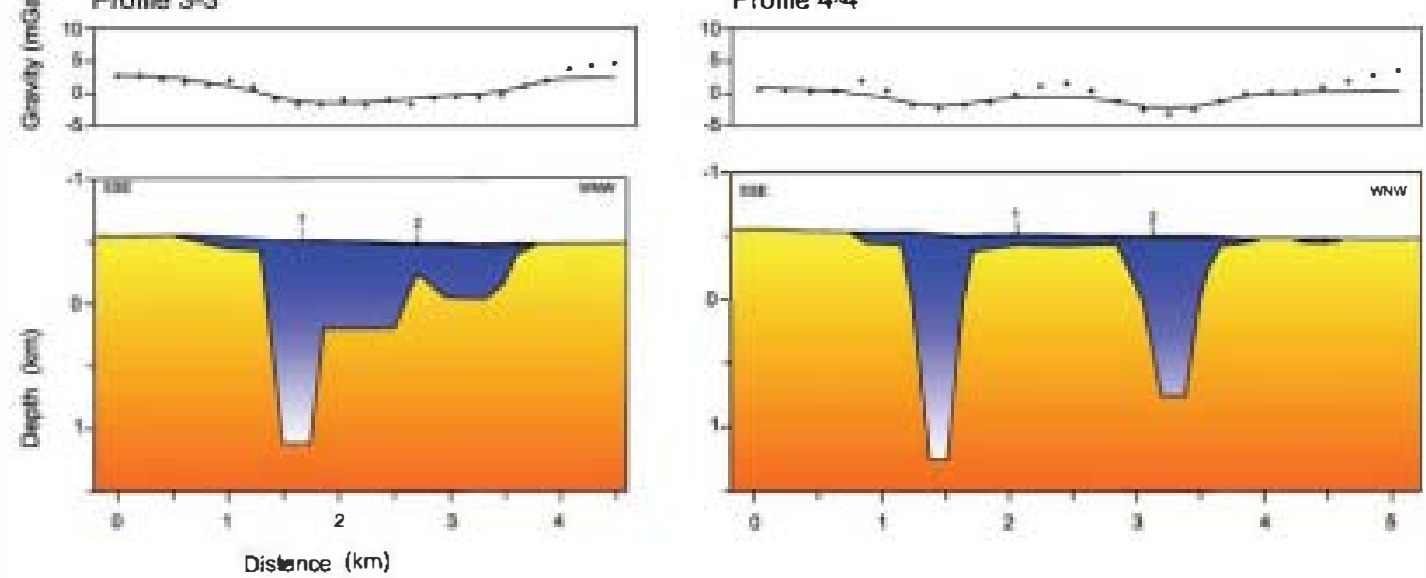

Fig. 6. Results $\bullet$ the gravity study. (a) The residual gravity map of the El Hong• pluton is characterized by two well-defined and north south negative anomalies separated by a positive an॰maly. The hatched line shows the contour of the El Hong pluton. Contour interval is $0.5 \mathrm{mGal}$; UTM cœordinates. Red dots indicate measuring sites. (b) Modelled gravity profiles. Models 1 and 2 correspond to ransverse sections whereas models 3 and 4 are parallel to the elongation of the pluton. Using representative density values of $2.64 \mathrm{~cm}{ }^{3}$ and $2.82 \mathrm{sm}$ for trondhjemite and host rock, respectively (see text for explanation), these profiles reveal significant changes in the orientation of the granite host-rock contact, which canuot be extap॰lated from the field or AMS struc aral data alone. 
trondhjemite body, which we interpret as two NNE SSE roots in the Hongo pluton. To the west, the trondhjemite extends to $11.25 \mathrm{~km}$ below sea level. The eastern negative minimum was fitted using a $1.75 \mathrm{~km}$ body thickness. Maximum values are related to a trondhjemite depth of a few tens of metres.

\section{Discussion}

\section{Fault-controlled ascent of the magma}

The emplacement of the Hongo pluton is post-kinematic in relation to the penetrative structures of the country rocks related to the Famatinian orogeny, as evidenced by the sharp and discordant contacts between the granite and the country rocks (Figs 1 and 2). However, the parallelism and elongate shapes of the Calmayo and Hongo plutons (Fig. 1) suggest some form of tectonic control during the formation (ascent andor emplacement) of both plutons. In this regard, it is worth noting that plutons related to wrench zones often display elongate shapes in map view (Hutton 1988; Hutton \& Reavy 1992).

The interplay between faulting and magmatism often occurs during the ascent of the magma or at the locus of granite emplacement, and has been widely reported from studies of synkinematic granites associated with contractional (Tobish \& Paterson 1990), extensional (Hutton et al. 1990; Bouillin et al. 1993) and strike-slip shear zones (Guillet et al. 1985; Hutton \& Reavy 1992). There are several possible reasons for such interactions; for instance, shear zones may form laminar discontinuities with lower strength than the surrounding wall rocks, or movements along releasing braided strike-slip faults may produce local extensional stress fields (Vigneresse \& Bouchez 1997). Consequently, fracture zones can act as channels for the rapid ascent of granite magma (Clemens \& Mawer 1992; Cruden et al. $1999 a, b)$ and make space for the emplacement of the magma into the continental crust (Dehls et al. 1998; Petford et al. 2000). On the other hand, the thermal weakening induced in the country rocks by the storage of huge volumes of hot magma may facilitate the development of accommodation faults along the intrusion edges, as suggested by natural examples (Aranguren et al. 1997) and demonstrated by analogue models of granite intrusions in extensional settings (Román Berdiel et al. 2000). By using field, AMS and gravity data, this detailed structural study of the Hongo pluton provides a new view on the interactions between granites and shear zones, even for a supposedly post-tectonic granite, because the ascent and emplacement of magma were controlled by buried fractures.

Field and AMS data reveal a fairly homogeneous internal structure characterized by four main features: (1) the steep dips of the granite layering and the foliations; (2) the steep plunge (mean plunge $c$. $60^{\circ} \mathrm{SSE}$ ) of the lineation; (3) the strong obliquity of the dominant north-striking foliation to the ENE elongation of the granite body; (4) the development of fine-grained facies showing ENE foliations in the long margins of the pluton. At first glance, such features point to the growth of the granite massif as a steepsided plug extending deep into the continental crust. Together with the two narrow bands located along the northern and southern pluton margins, where foliation is parallel to the contact with the country rocks, the overall trajectories of the foliation seem to delineate sigmoidal patterns (Fig. 5). Sigmoidal trajectories of magmatic foliation, first described in the St. Sylvestre granite of the French Massif Central (Mollier \& Bouchez 1982) and subsequently recognized in most of the Pyrenean granites (Gleizes et al. 1999), are interpreted as magmatic shear zones (Mollier \& Bouchez 1982; Gleizes et al. 1999). The sigmoidal pattern of the Hongo pluton might be interpreted in the same way and the ENE foliation of the external facies be explained by deflections of the north-trending foliation of the central facies during the motion of a strike-slip shear zone. However, the S- or Z-shape of such sigmoid foliation is not well established, nor is the corresponding dextral or sinistral shear sense

The structural interpretation for the field data must be modified in light of the results from the gravity study, a conclusion that is often reached when the shape of the pluton at depth is also taken into account (Améglio \& Vigneresse 1999). The gravity modelling of the E1 Hongo granite is characterized by the existence of two negative gravity anomalies with NNE SSW elongation below the central portion of the pluton connected with a very thin and flat.lying granite sheet. Such a $3 \mathbf{D}$ shape implies that this pluton can no longer be considered as a vertical plug, but may be regarded as a very thin and flat-lying granite tongue resting on two steep-sided granite walls (Figs 6 and 7). From their funnel shape and the existence of lineations with steep plunges, we interpret the gravity anomalies as root zones that acted as feeder conduits for the construction of the pluton. The subsequent lateral spreading of magma would end in the coalescence of these two initially independent granite plugs. The synform that preserves the roof of the pluton marks the suture zone between them (Fig. 7), by analogy with the interpretation of equivalent structures in salt canopies (Jackson \& Talbot 1993). In this context, the rhythmic ganite layers display a uniform north south and steep-dipping orientation nearly concordant with the negative gravity anomalies (Figs 5 and 6) whereas, at first glance, the lateral spreading of magma should promote the development of flat foliations and granite layers. It is reasonable to suppose that these layers record sequential magma inputs ascending as vertical sheets through the feeder dykes with very

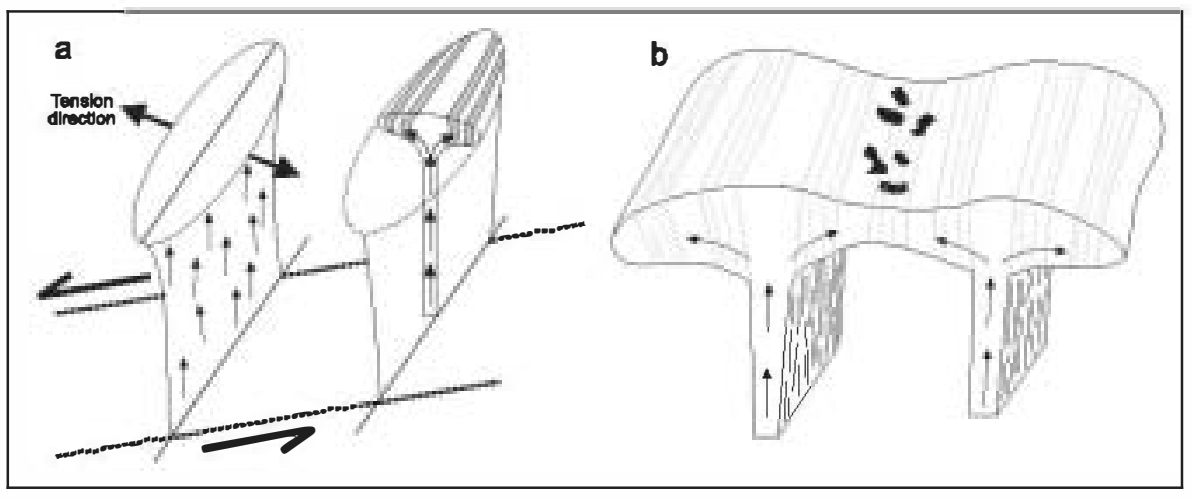

Fig. 7. Sketch showing proposed scheme for the emplacement of the El Hongo pluton. (a) North-rending en echelon conduits related to a buried sinistral shear zone. (b) Canopy resulting from the coalescence of single injections of magma converging to the central part of the pluton. Black polygons represent roof pendants of the host rocks, preserved in the synform developed in the suture zone between the two coalescing plugs. 
short breaks between magma extraction. A likely consequence of repeated dyke-like intrusions is that older and younger magmatic pulses probably had different viscosities when they came into contact, as they crystallize quickly and in different times. This could be an efficient mechanism to prevent magma mixing and preserve the magmatic layering. The small volume of magma supply required to form the El Hongo pluton and its emplacement at a shallow level would ensure the fast cooling required to freeze the magma at the emplacement site quickly after its ascent (Fig. 7)

The obliquity of the NNE-trending feeder channels with respect to the ENE elongation of the pluton suggests that they correspond to en echelon fractures associated with a buried sinistral strike-slip shear zone parallel to the pluton elongation (Fig. 7). Similar kinematic interpretations, based on AMS map patterns alone, have been proposed for plutons in the central Sierra Nevada, California (Tobisch \& Cruden 1995), and a large batholith in the Variscan belt of Spain (Aranguren et al. 1997). However, map patterns that might indicate fracture feeding of plutons are difficult to document because of subsequent emplacement-related flow (Tobish \& Cruden 1995). This question is overcome in the present study because the vertical feeder channels are indicated by the negative anomalies of the gravity map (Fig. 6). The angle of some $20^{\circ}$ between the NNE-trending feeder channels and the north-trending layers suggests a small counterclockwise rotation of formerly NNE-trending layers, consistent with the sinistral motion of the strike-slip shear zone. The incipient solid-state deformation and the ENE-trending foliation of the marginal, fine-grained facies can be related to this rotation. On the other hand, the lack of solid-state deformation in the central facies is consistent with the maintenance of high-temperature conditions (close to the granite solidus) during the rotation, as such thermal conditions favour the concentration of deformation in narrow bands (Fleitout \& Froidevaux 1980). An interesting structural result of this evolution is that the fabric of the overall pluton reflects processes that occur at the emplacement level (Cruden et al. 1999a; Gleizes et al. 1999). The very constant orientation of the magnetic fabrics is frequently explained by an increment of regional tectonic strain that is frequently achieved in transpressional settings (Saint Blanquat et al. 1998). A common feature of granitic plutons emplaced during transpressional tectonics is that they are commonly elongated and concordant with the major structures, folds and shear zones developed in the country rocks, as is illustrated by plutons of the Sierra Nevada mountains, in California (Tobish \& Cruden 1995), the Axial Zone of the Pyrenees (Gleizes et al. 1998) and the Variscan belt of Spain (Vegas et al. 2001). However, we rule out a similar interpretation for the El Hongo pluton, because it is oblique, nearly perpendicular, to the regional structures of the country rocks (Fig. 1b). As an alternative interpretation, we consider that the very constant orientation of the magnetic fabrics in the E1 Hongo pluton (Fig. 5a) does not necessarily require an increment of regional tectonic strain, but rather that it points to formation of the pluton by amalgamation of countless vertical magmatic sheets ascending through vertical feeder conduits (Fig. 7). The widespread preservation of vertical magmatic layers is consistent with rapid cooling. This mechanism of forming composite plutons from individual sheets that were added sequentially could be applicable to many other plutons and batholiths with similar foliation patterns (Tobish \& Cruden 1995; Aranguren et al. 1997). Nevertheless, the evidence of sequential intrusions would vanish, and be difficult to recognize, in granites whose fabrics were acquired at high temperature during slow cooling.
Was the emplacement controlled by the post-Famatinian extension?

It is clear that the generation of the thin and flat granite canopy above the vertical feeding zones requires lateral spreading of the magma. However, in the El Hongo pluton the mechanism for the vertical arrest and accumulation of magma at the emplacement site is poorly constrained and difficult to reconcile with the known structure of the granite and the country rocks. According to the current structural knowledge of the region (Baldo et al. 1996; Martino 2003) there is a penetrative foliation dipping steeply to the ENE, and this seems to militate against the existence of a flat-lying boundary that could act as a barrier to the vertical migration of the magma. We suggest that such a boundary could be provided either by a buried top-to-the-west thrust contact associated with the nearly east west compressional field produced during the subduction of the Famatinian arc or by a detachment related to a possible post-Famatinian extensional event. It is worth noting, however, that the compressional deformation of the Sierra Chica de Córdoba is well established (Martino et al. 1995; Baldo et al. 1996) whereas the late extensional tectonics is not.

\section{Conclusions}

Anisotropy of magnetic susceptibility (AMS) analyses combined with field structural data and microstructural observations allow us to correlate the fabrics of magmatic and magnetic origin within the ferromagnetic E1 Hongo pluton, a trondhjemite massif belonging to the pre-Andean basement of the Sierras Pampeanas of central Argentina. These structural data have been complemented by a gravity survey over the pluton and adjacent country rocks to obtain a detailed 31 image of the pluton's shape. Magnetic foliations strike north south and dip steeply to the west but in the marginal facies the foliation becomes parallel to the ENE WSW pluton contacts. Magnetic lineations mostly trend north south and plunge SE. Gravity data reveal that the pluton is in the form of a very thin and flat sheet resting on two NNE SSW-trending root zones located below the central portion of the pluton. These root zones represent feeder dykes that exploited tension fractures. We suggest that the emplacement of the El Hongo pluton took place during the action of a buried sinistral shear zone parallel to the elongation of the pluton and was probably associated with the late extensional exhumation of the Famatinian domain.

We thank A. R. Cruden, C. Fernández and K. J. W. McCaffrey for constructive revisions of a previous version of the manuscript. This work was funded by the research projects CGL2004-00701/STE, UPV/EHU (9UPV 0001.310-14478/2002) from Spain and 18/C097 SECyT-FOMEC 554 (Universidad Nacional de Río Cuarto) from Argentina.

\section{References}

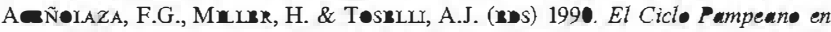
el Norøeste Argentinø. Universidad Nacional de Tucumán, Serie Correlación Geológica, 4.

Amégle, L. \& VYGNeresse, J.L. 1999. Geophysical imaging of the shape of granitic intrusions at depth: a review. In: Casrre, A., Frrnán@ez, C. \& VIGNRResse, J.L. (eds) Understanding Granites: Integrating New and Classical Techniques. Geological Society, London, Special Publications, 168, $39-54$.

AMcr, M. \& Bøuchez, J.L. 1989. Susceptibilité magnétique et zonation du batholite granitique de Cabeza de Araya (Extremadura, Espagne). Comptes Rendus de l'Acudémie des Sciences, 308, 1171-1178.

Aranguren, A., Tunía, J.M., Bouchez, J.L. \& Vigneresse, J.L. 1996. The 
Guitiriz granite, Variscan belt of northern Spain: extension-controlled emplacement of magma during tectonic escape. Eath and Planetary Science Letters, 139, 165-176

aranguren, A., lakrra, F J., Carra ane, M., Curvas, J. \& Tunía, J.M. 1997. The Los Pedroches Batholith (Southern Spain): polyphase interplay between shear zones in ranstension and setting of granites. In: Bouchrz, JL., Hurrøn, D.H.W. \& Srmprns, W.E. (eds) Granite: From Segregation •f Melt to Emplacement Fabrics. Kluwer, Dordrecht, 215-229.

BaLıe, E.G., Drmangue, M. \& Marmne, R.D. 1996. Evolution of the Sierras de Córdoba, Argentina. Tectonø physics, 267, 121-142.

BLUNeNFu, P. \& Bouchez, J.L. 1988. Shear criteria in granite and migmatite deformed in the magmatic and solid states. Journal of Structural Geology, 10, $361-372$.

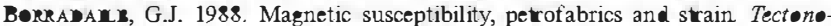
physics, 156, 1-20.

Borramaly, G.J. \& HrNRY, B. 1997. Tectonic applications of magmetic susceptibility and its anisotropy. Earth-Science Reviews, 42, 49-93.

Bovche Z, JL. 1997. Granite is never isotropic: an introduction to ASM studies of granitic rocks. In: Bøuchez, J.L., Hurren, D.H.W. \& STmprens, W.E. (eds) Granite: From Segregation of Melt to Emplacement Fabrics. Petrology and Structural Geology. Kluwer, Dordrecht, 95-112.

Boumurn, J.P., Bøumez, J.L., Lespinassı, P. \& Premek, A. 1993. Granite emplacement in an extensional setting: an ASM of the magmatic structures of Monte capanne (Elba, Italy). Eanth and Planetary Science Letters, 118, 263279.

CLemens, J.D. 1998. Observations on the origins and ascent mechanisms of granitic magmas. Joumal of the Geological Sociery, London, 155, 843-851.

CLneNS, J.D. \& MAWRe, C.K. 1992. Granitic magma transport by fracture propagation. Tectonophysics, 204, 339-360

Corry, CE. 1988. Laccoliths: Mechanics of Emplacement and Growth. Geological Sociery of America, Special Papers, 220.

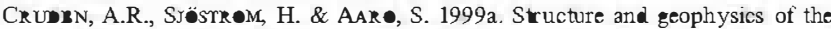
Gasborn granite, Central Sweden An example of facture-fed asynunetric pluton emplacement. In: CASTre, A., Frrnánerz, C. \& Vrgneresse, J.L. (eds) Understanding Granites: Integrating New and Classical Techniques. Geological Society, London, Special Publications, 168, 141-160.

CRUmen, A.R., Torsh, O.T. \& LaUneau, P. 1999b. Magnetic fabric evidence for conduit-fed emplacement of a tabular intrusion: Dinkey Creek Pluton, central Sierra Nevada batholith, California. Joumal of Geophysical Research, 104, $10511-10530$

Darla Salda, L.H., Dalume, I.W.D., Crngelani, C.A. \& Varerla, R. 1992. Did the Taconic Appalachians continue into South America? Geology, 20, 10591062

Damla Salua, L.H., Lomez luchi, M.G., Cingelani, C.A. \& Vareya, R. 1998. Laurentia-Gondwana collision: the origin of the Famatinian-Appalachian orogenic belt (a review). In: PANreruesr, R.J. \& RAPrLA, C.W. (eds) The Proto-Andean Margin of Gondwana. Geological Society, London, Special Publications, 142, 219-234.

DAIzel, I.W.D. 1992. On the organization of American plates in the Proterozoic, and the breakout of Laurentia. GSA Today, 2, 237-241.

DALZEL, I.W.D. 1997. Neoproterozoic-Palaeozoic geography and tectonics, review, hypothesis, envirommental speculation. Geological Sociery of Americ Bulletin, 109, 16-42

Derr.s, J.D., CRUurn, A.R. \& VIGNmesse, J.L. 1998. Fracture control of late Archean pluton emplacement in the Northern Slave Province, Canada Joumal of Structural Geology, 20, 1145-1154.

Furrour, L. \& Fronevaux, C. 1980. Thermal an mechanical evolution of shear zones. Joumal of Structural Geology, 2, 159-164.

Gleres, G., Lmolanc, D. \& Bouchez, J.L. 1998. The main phase of the Hercynian orogeny in the Pyrenees is a dextral transpression. In: Hor sWøRTH, R.R., STRACHAN, R.A. \& Dewry, J.F. (eds) Continental Transpressional and Transtensional Tectonics. Geological Society, London, Special Publications, 135, 267-273.

Gleres, G., Lemlanc, D., Sanrana, V., Orrvink, Ph. \& Buvchez, J.L. 1999. Sigmoidal structures featuring dextral shear during emplacement of the Hercynian ranite complex of Cauterets-Panticosa (Pyrenees). Joumal of Structural Geology, 20, 1229-1245.

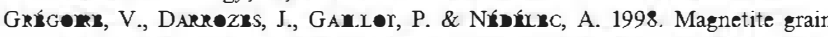
shape fabric and distribution anisotropy vs rock magnetic fabric: a threedimensional case study. Journal of Structural Geology, 20(7), 937-944.

Gur.ler, P., Bøumz, J.L. \& Vrgneresse, J.L. 1985. Le compléxe granitique de Plouaret: mise en evidence structurale et gravimétrique de diapers emboités Bulletin de la Societé Géologique de France, 8, 503-513.

HrouA, F. 1982. Magnetic anisotropy of rocks and its application in geology and geophysics. Geophysical Survey, 5, 37-82.

Hurr $\bullet$, D.H.W. 1988. Granite emplacement mechanisms and tectonic controls: inferences from deformation studies. Transactions of the Royal Socieity of Edinburg: Earth Sciences., 79, 245-255.
Hurren, DH.W. 1992. Granite sheeted complexes: evidence for the dykin ascent mechanism. Iransactions of the Royal Socieity of Edimburgh: Earth Sciences, 83, 377-382

Hurrøn, D.H.W., Depstak, T.J., Bkøwn, P.E. \& Brexuk, S.D. 1990. A new mechanism of granite emplacement: intrusion in active extensional shear zones. Nature, 343, 452-455.

Hurr N, D.H.W. \& RrAvY, R.J. 1992. Strike-slip tectonics and granite emplacement. Tectonics, 11, 960-967.

JAexs N, M. 1991. Anisotropy of magnetic remanence: a brief review of mineralogical sources, physical origins, and geological applications, and comparison with susceptibility anisotropy. Pure and Applied Geophysics, 136, $1-28$

Ja exson, M., GRubrk, W., Marvin, J. \& BankrRe, S.K. 1988. Partial anhysteretic remanence and its anisotropy: applications and grain size dependence. Geophysical Research Letters, 15, 440-443.

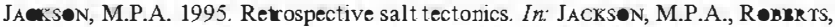
D.G. \& Snerson, S. (eds) Salt Tectonics: a Global Perspective. AAPG Memoirs, 65, 1-28

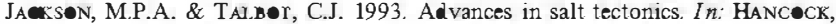
P.L. (ed.) Continental Deformation. Pergamon, Oxford, 159-179.

Jurnex, V. 1981. Characterization of the magnetic fabric of rocks. Tecton physics, 79, 63-70.

Kranmer, P., Escay $\bullet$ LA, M.P. \& Marmne, R.D. 1995. Hipótesis sobre la evolución neoproterozoica de las Sierras Pampeanas de Córdoba $\left(30^{\circ} 4{ }^{\prime}\right.$ $32^{\bullet} \mathbf{0}^{\prime}$ 'S). Revista de la Asøciación Geológic Argentina, 50, 47-59.

Ilamáís, EJ. 2003. Geologia de los Cuerpos Igneos. Asociación Geológica Argentina, Serie B, Didáctica y Complementaria, 27.

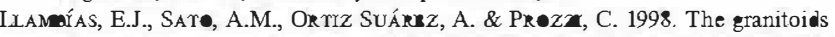
of the Sierra de San Luis. In: PANkHursr, R.J. \& RAPrla, C.W. (eds) The Proto-Andean Margin of Gondwana. Geological Society, London, Special Publications, 142, 325-341.

Mainerie, D.H., Bøuchez, JL., Blumenferm, P. \& Tubía, J.M. 1986. Dominant c-slip in naturally deformed quartz: implications for dramatic plastic softening at high temperatures. Geology, 14, 819-822.

MARrine, DR. 2003. Las fajas de deformación ductile de las Sierras Pampeanas de Córdoba: una reseña general. Revista de la Asociación Geológic Argentin a, 58, 549-571.

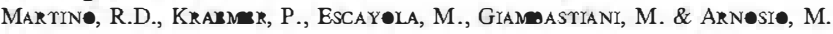
1995. Transecta de las Sierras Pampeanas de Córdoba a los $32^{\bullet} \mathrm{S}$. Revista de la Asociación Geológic Argentina, 50, 60-77.

Molumk, B. \& Bovchez, JL. 1982. Structuration magmatique du complexe granitique de Brâme-St Sylvestre-St Goussaud (Limousin, Massif Central français). Comptes Rendus de l'Académie des Sciences, Série II, 294, 13291334

Orriz Súnzz, OA., Prezzr, C. \& Llaiveras, E.J. 1992. Geología de la parte sur de la Sierra de San Luis y granitoides asociados. Estudios Geológicos, 48, 269-277.

PANKmuRST, R.J. \& RAPrLA, C.W. 1998. The Proto-Andean margin of Gondwana: an in troduction. In: Pankurursr, R.J. \& RaprLA, C.W. (eds) The ProteAndean Margin of Gondwana. Geological Society, London, Special Publications, 142, 3-9.

PrTfors, N., CRUUn, A.R., MCCAFFrey, K.J.W. \& VIGNmesse, JL. 200 Dynamics of granitic magma formation, ransport and emplacement in the Earth's crist. Nature, 408, 669-673.

Pricr, N.J. \& Cosgrove, J.W. 1990. Analysis of Geoløgical Structures. Cambridge University Press, Cambridge

Raprla, C.W., Panreyurst, R.J., Caseurr, C., Baine, E., SaAvemka, J., GAIINDe, C. \& FANNING, C.M. 1998. The Pampean orogeny of the southern proto-Andes: Cambrian continental collision in the Sierras de Córdoba. In: PANkHunsr, R.J. \& Raperla, C.W. (eds) The Proto-Andean Margin of Gondwana. Geological Society, London, Special Publications, 142, 181-218.

RecHerre, P. 1987. Magnetic susceptibility of the rocks matrix related to magmatic fabric studies. Joumal of Structural Geology, 9, 1015-1020.

Recherrs, P., JACKS N, M. \& AUBouRG, C. 1992. Rock magnetism and the interpretation of anisotropy of magnetic susceptibility. Reviews of Geophysics, 30, 209-226.

Román Brominl, T., Aranguren, A., Curvas, J., Tumía, J.M., Gapars, D. \& BRUN, J.P. 2000. Experiments on granite intrusion in transtension In: Venomurle, B., Marr, Y. \& VrGneresse, J.L. (eds) Salt, Shale and Igneous Diapirs in and and Europe. Geological Society, London, Special Publications, $174,21-42$

SaAvemea, J.P., Tosmlir, A., Ressi, J., Prulitmke, E. \& Duranı, F. 1998. The early Palaeozoic magmatic record of the Famatinian System: a review. In: Pannwunsr, R.J. \& Raplex, C.W. (eds) The Proto-Andean Margin of Gondwana. Geological Society, London, Special Publication, 142, 283-297.

Sarnr Blanevar, M., Tweff, B., Tryssne, C. \& Vrgneresse, J.L. 1998 Transpressional kinematics and magmatic arcs. In: Hol SWorm, R.R., STRACHAN, R.A. \& Dewry, J.F. (eds) Continental Iranspressional and 
Transtensional Tectonics. Geological Society, Iondon, Special Publications, $135,327-340$.

Sermor, M.W. \& TH॰mes, A.B. 1996. Epidote in calc-alkaline magmas: an experimental study of stability, phase relations and the role of epidote in magmatic evolution. American Mineralogist, 81, 424-474.

Sial, A.N., T-smlly, A.J., SaAvrdra, J., Parama, M.A. \& Frrremra, V. 1999 Emplacement, petrological and magnetic susceptibility characteristics of diverse magmatic epidote-bearing granitoid rocks in Brazil, Argentina and Chile. Lithøs, 46, 367-392.

Sms, J., IrRlane, T. \& Camaere, A. r ax. 1998. U-Pb, Th-Pb and $\mathrm{Ar}-\mathrm{Ar}$ geochronology from the southern Sierras Pampeanas, Argentina: implications for the Paleozoic tectonic evolution of the western Gondwana margin In: PANkhursr, R.J. \& RAPri.A, C.W.er AL. (eds) The Proto-Andean Margin of Gondwana. Geological Society, London, Special Publications, 142, 259-281.

T•BrSCH, O.T. \& CRUMrN, A.R. 1995. Fracture-controlled magma conduits in an obliquely convergent continental magmatic arc. Geology, 23, 941-944.

TøBSH, O.T. \& PArmesen, S.R. 1990. The Yarra granite: an intradeformational pluton associated with ductile thrusting, Lachlan Fold Belt, southeastern
Australia. Geological Socieity of Americ Bulletin, 102, 693-703.

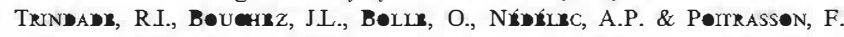
2001. Secondary fabrics revealed by remanence anisotropy: methodological study and examples from plutonic rocks. Geophysical Journal International, $147,310-318$.

VeGAS, N., ARANGURren, A. \& TUMÁ, J.M. 2001. Granites built by sheeting in a fault stepover (the Sanabria Massif, Variscan Orogen, NW Spain). Terra Nova, 13, 180-187.

VIGNeresse, J.L. 1995. Crustal regime of deformation and ascent of granitic magma. Tecton physics, 249, 187-202.

Vygneressr, J.L. \& Bøumrz, J.L. 1997. Successive granitic magma batches during pluton emplacement: the case of Cabeza de Araya (Spain). Journal of Petrology, 38, 1767-1776.

WhImeYne, SJ. \& Smesen, C. 2003. High strain-rate deformation fabrics characterize a kilometers-thick Paleozoic fault zone in the Eastern Sierra Pampeanas, central Argentina. Joumal of Structural Geology, 25, 909-922.

ZnN, E-A. \& HANmLARSTR・M, J.M. 1984. Magmatic epidote and its petrologic significance. Geology, 12, 515-518. 